https://doi.org/10.15407/dopovidi2021.06.078

УДК 661.183.1+615.47

I.В. Кононко, https://orcid.org/0000-0003-1976-7116

Н.В. Бошицька, https://orcid.org/0000-0003-2241-1161

В.П. Сергєєв, https://orcid.org/0000-0001-9417-2548

В.Д. Кліпов, https://orcid.org/0000-0002-5634-1512

Н.В. Кононко, https://orcid.org/0000-0002-5634-1512

Інститут проблем матеріалознавства ім. І.М. Францевича НАН України, Київ

E-mail: nata25lia@gmail.com

\title{
Вуглецевий наноструктурний матеріал для багаторазових захисних масок
}

Представлено академіком НАН України С.О. Фірстовим

Досліджено комплекс властивостей активованого вуглецевого волокнистого наноструктурного матеріалу (АВВНМ), розробленого авторами, як фільтрувального прошарку багаторазових захисних масок для обличчя. Показано, що АВВНМ притаманна висока здатність до поглинання основних забруднювачів довкілля (фенолу; металів $\mathrm{Pb}^{2+}, \mathrm{Sr}^{2+}, \mathrm{Cu}^{2+}, \mathrm{Ni}^{1+}, \mathrm{Co}^{2+}, \mathrm{Al}^{3+}, \mathrm{Cs}^{2+}$; хлорпохідних; радіоактивних легких продуктів поділу та ін.) і речовин білкової природи. Встановлено, що АВВНМ виявляє бактеріостатичні властивості, які можуть бути трансформовані в бактерицидні шляхом нанесення на його поверхню біологічно активних речовин. Доведено, що АВВНМ відповідає вимогам до медичних матеріалів і може бути рекомендований для виготовлення масок для захисту органів дихання.

Ключові слова: маски для захисту органів дихання, активований вуглецевий волокнистий наноструктурний матеріал, фізико-хімічні властивості.

Створення сучасних захисних масок для обличчя в умовах всесвітньої пандемії та екологічних катастроф є надзвичайно актуальним. Сьогодні вчені всього світу активно працюють над розробкою ефективних захисних масок для боротьби з поширенням коронавірусу SARS-CoV-2. Встановлено, що високий рівень забруднення повітря є фактором підвищення ризику смертності від COVID-19. Так, вчені Гарвардського університету стверджують, що повітря з дрібними частинками спричиняє підвищення смертності від COVID-19 на 15 \%. Подібні дослідження проведені і в Італії, результати яких свідчать про вищу смертність від COVID-19 у забруднених районах Ломбардія та Емілія-Романья (12 \% проти 4,5 \% в інших районах) [1]. Зважаючи на вищезгадане, розробляючи захисні маски для обличчя,

Ци ту вання: Кононко І.В., Бошицька Н.В., Сергєєв В.П., Кліпов В.Д., Кононко Н.В. Вуглецевий наноструктурний матеріал для багаторазових захисних масок. Допов. Наи. акад. наук Укр. 2021. № 6. C. 78-86. https://doi.org/10.15407/dopovidi2021.06.078 
доцільно вибирати фільтрувальні матеріали, здатні максимально затримувати надходження з повітря до організму як вірусів та бактерій, так і промислових забруднювачів хімічної та фізичної природи (сполук важких металів, фенолу, формальдегіду, хлору та його сполук; радіоактивних летких продуктів поділу; шматочків сажі, асфальту, пилу, кіптяви тощо) [2]. Також треба враховувати сезонні пилкові алергени та мікроорганізми, що з'являються в повітрі ранньою весною - пилок дерев, злаків, бур'янів та спори пліснявих грибів. У сільській місцевості у повітрі присутні ще й викиди тваринництва - додатковий різновид біологічного забруднення повітря (органічний пил, токсини від мікроорганізмів та гази - аміак і метан.

За даними Air Quality Index (AQI) найбільшу концентрацію складають забруднювачі $\mathrm{PM}_{2.5}$ та $\mathrm{PM}_{10}$. Це пил розміром 2,5-10 нм, що являє собою суміш неорганічних іонів, дрібні краплі води, метали, вуглеводні [2]. Частинки такого пилу практично не осідають, а зависають у повітрі, легко проходять крізь біологічні бар'єри в організм - носову порожнину, верхні дихальні шляхи, бронхи, альвеоли, пошкоджують легені та проникають у кровоносну систему. Ці аерозольні частинки відіграють ключову роль у поширенні інфекції [3]. Мікроорганізми, зокрема новий коронавірус, у повітрі теж знаходяться в стані аерозолю - у складі колоїдної системи з повітря, крапель рідини або твердих частинок (до трьох годин після кашлю чи чхання інфікованих).

Захисні маски (напівмаски), медичні (хірургічні, процедурні) та повсякденні для індивідуального використання - універсальний засіб захисту органів дихання від різних забруднювачів повітря з ефективністю від 20 \% до 90 \% [4]. Вимоги до медичних масок викладені в ДСТУ EN 14683:2014; 136:2003; 140:2004 та ДСТУ ISO серій 10993; 11737; 22609; 9001; директиві 93/42/EЕC тощо. Вибираючи матеріали фільтра та прошарків, особливу увагу потрібно приділяти ступеню чистоти (відсутності твердих частинок, мікроорганізмів та органічних залишків). Окрім цього, важливими є гіпоалергенність, біосумісність, повітропроникність і відсутність запаху, стійкість до бризок біологічних речовин та рідин, ефективність бактеріальної фільтрації. Керуючись цими вказівками, для виготовлення масок зазвичай застосовують такі матеріали: марля; щільні натуральні волокна - бавовна, шовк, фланель; неткані синтетичні матеріали неопрен та мельтблаун; поліпропіленовий матеріал спанбонд та ін.

Останнім часом для виготовлення захисних масок почали застосовувати вуглецеві матеріали, як один із прошарків виробу. Серед них - наноматеріали з широким спектром наноформ, які значно розширюють можливості сорбції. Так, відомі маски та респіратори китайського виробництва фірм “Nefoume”, “Aхоn”, “Doctor mask” та “Лататана”, до складу яких входять активовані вуглецеві волокна (ABB), та захисні маски вітчизняного виробництва (пат. 70129 Україна. Захисна маска. Опубл. 15.09.2004; пат. 60425 Україна. Лицьова маска для захисту органів дихання. Опубл. 25.06.2011) і три- та п’ятишарові маски “Megalogic”.

Є відомості, що вугільний фільтр підвищує захисні властивості масок щодо бактерій (до 90 \%), пилу, алергенів пилку, шкідливих газів (бензол, аміак, формальдегід) та ін. Встановлено [5], що вуглецевмісні матеріали (графіт, ВНТ, наноалмази та алмазна шихта) здатні також взаємодіяти з вірусами грипу А і В, поліомієліту, бактеріофагами та видаляти їх з розчину.

Для покращення біоспецифічних властивостей інколи проводять модифікацію фільтрувального (зокрема, вуглецевого) прошарку масок і респіраторів іонами та наночастин- 
ками благородних металів, здебільшого сріблом (пат. 49742 Україна. Спосіб додання захисним маскам антимікробних властивостей. Опубл. 11.05.2010; пат. 49744 Україна. Лицьова маска для захисту від вірусних і бактерійних збудників хвороб. Опубл. 11.05.2010; пат. 50693 Україна. Медична маска. Опубл. 25.06.2010). Відомо, що срібло є безпечним і натуральним антисептиком, який пригнічує понад 700 видів хвороботворних мікроорганізмів, серед яких стафілококи, стрептококи, бактерії дизентерії, черевного тифу та ін. [6]. Досліджено також основні закономірності адсорбції вірусу грипу (штам А/Ленінград/125/ 84/H1N1) на металізованих АВВ [7]. Встановлено, що срібловмісні волокна здатні сорбувати віруси грипу в прямій залежності від вмісту металу на сорбентах (підвищується сорбція та вибірковість сорбції вірусів грипу).

Активований вуглеволокнистий наноструктурний матеріал (АВВНМ), створений в Інституті проблем матеріалознавства ім. I.М. Францевича НАН України, з рядом унікальних властивостей (гіпоалергенність, атоксичність, біосумісність, повітропроникність, відсутність запаху) [8] є перспективним для розробки захисних масок.

Мета роботи - оцінити можливість використання АВВНМ для створення ефективної, з підвищеним ресурсом, багаторазової захисної маски для обличчя; проаналізувати та узагальнити властивості АВВНМ як фільтрувального прошарку маски.

Методи та матеріали. За об’єкт дослідження вибрано зразок АВВНМ з об'ємною ємністю $\left(V_{s}\right)$ 1,0 cм c $^{3}$ г, виготовлений у вигляді тканини, що відкриває можливість для його технологічного використання як матеріалу масок. АВВНМ містить у своїй структурі наноцибулини, нанографіт, нановолокна, нанотрубки, нанонитки [9]. Для порівняння використовували матеріали: карболен (активоване березове вугілля), графітову тканину ТГН-2МК (РФ), СКН (вуглецевий синтетичний сорбент на основі полімерних смол), волокнистий вуглецевий сорбент актилен (НДІ “Хімволокно”), УУТ-2 (ТУ 6-06-492-75) та марлю медичну (ГОСТ 9412-93).

Мікроструктуру зразків досліджували за допомогою сканувального електронного мікроскопа (рентгенівський мікроаналізатор “Superprobe-733”, JEOL, Японія). Прискрювальна напруга 25 кВ. Роздільна здатність 100 нм.

3 метою встановлення складу хімічних елементів було проведено енергодисперсійний рентгенівський аналіз зразків. Питомий електроопір визначали за нестандартною, розробленою авторами методикою за допомогою моста постійного струму МО-62.

Протимікробну активність АВВНМ вивчали in vitro відносно санітарно-показових клінічних штамів бактерій: Escherichia coli (серотип 0 III B:4, регламентований ГОСТ 2874-82 “Вода питна”), Staphylococcus aureus (серотип 5 CP5) та Pseudomonas aeroginosa (серотип O5 PAО1) з розрахунку $2 \cdot 10^{5}$ КУО/л (колонієутворювальних одиниць). Кінетику відмирання мікроорганізмів досліджено у дехлорованій, контамінованій добовою культурою кишкової палички, воді в присутності зразків АBВНМ та ABBHM-Ag $\left(2 \cdot 2\right.$ cм$\left.^{2}\right)$. Срібло наносили на зразок з водного розчину нітрату срібла. Через 0,5; 1 та 2 год контакту суспензію висівали на щільне живильне середовище в чашках Петрі. Посіви витримували в термостаті 24 год при температурі 37 ㅇ $\mathrm{C}$ визначали діаметр зони затримки росту бактерій. Контролем були посіви проб води, що не контактували з АВВНМ та ABBHM-Ag.

Для статистичної обробки результатів використовували програмиу Microsoft Excel, достовірність результатів визначали за $t$-критерієм Стьюдента. 

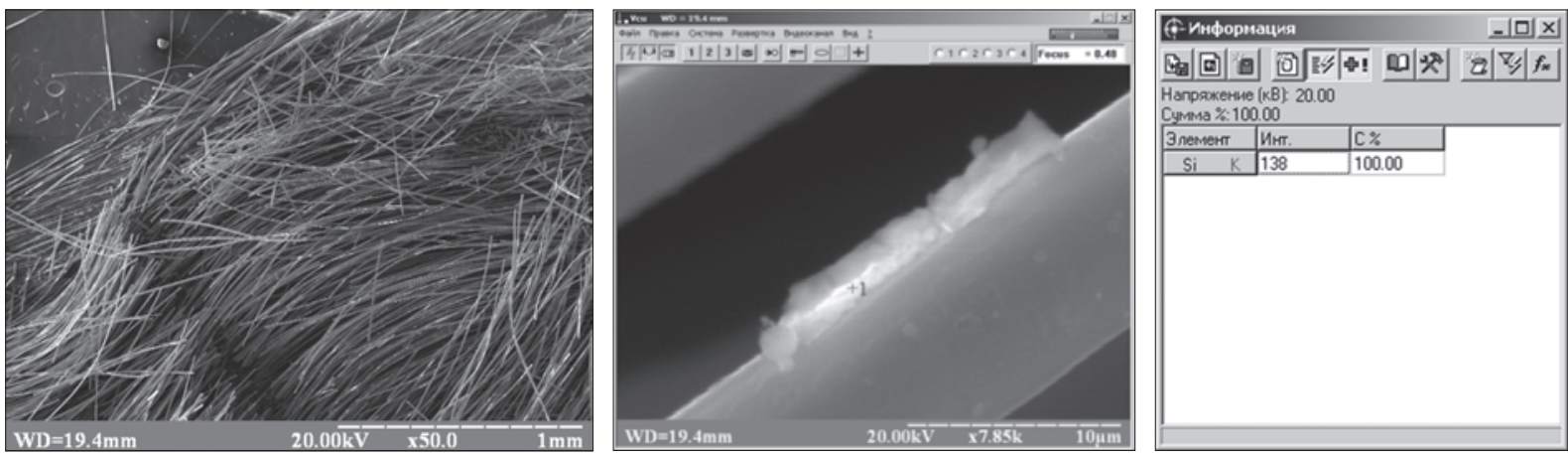

Puc. 1. Морфологія зразка АВВНМ (різне збільшення) та аналіз домішок у волокні в окремо взятих точках

Результати та ї обговорення. В наших попередніх дослідженнях встановлені властивості АВВНМ, корисні у виготовленні захисних масок: мала вага, низька поверхнева щільність, високорозвинена пориста поверхня, нановимірна структура, високі атмосферостійкість, хімічна, термічна та радіаційна стійкість, біостійкість та біоінертність [9]. АВВНМ за рядом своїх механічних властивостей (міцність на розрив та розривна деформація, визначені згідно з ГОСТ 29104.4-91, а також еластичність) наближається до якості традиційних перев’язувальних матеріалів. Окрім того, ми встановили достатній ступінь чистоти АВВНМ, відсутність твердих частинок, мікроорганізмів та органічних шкідливих домішок, що має велике значення для біосумісності матеріалу (рис. 1). Хімічний склад АВВНМ обмежується вуглецем - 96,32-97,738 \%; золою - 0,162-1,576 \%; гідрогеном - 0,6 \%; окси-

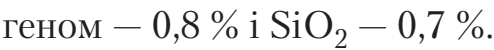

Для тканини масок важливим є можливість фільтрації повітря завдяки їі повітропроникності, капілярності, гігроскопічності тощо, а також сорбційній активності (здатності поглинати забруднювачі повітря). Так, показники капілярності та гігроскопічності АВВНМ у 3-3,5 раза перевищують аналогічні показники для марлі. Аеродинамічний опір матеріалу також є важливою характеристикою для виготовлення адсорбційних систем. Встановлено, що цей показник у АВВНМ удвічі нижчий, ніж у активованого вугілля марки СКТ-3 [10], що свідчить про кращу повітропроникність і уможливлює ефективне використання АВВНМ у масках, респіраторах, протигазах та інших фільтрувальних системах. Відомо, що наноструктурні сорбенти (до яких належить і АВВНМ) з високим співвідношенням поверхні та об'єму й контрольованими хімічними властивостями поверхні не мають обмежень, притаманних традиційним сорбентам. Так, у наших попередніх дослідженнях зафіксована висока здатність АВВНМ до поглинання основних забруднювачів довкілля (фенолу; важких та токсичних металів $\mathrm{Pb}^{2+}, \mathrm{Sr}^{2+}, \mathrm{Cu}^{2+}, \mathrm{Ni}^{1+}, \mathrm{Co}^{2+}, \mathrm{Al}^{3+}, \mathrm{Cs}^{2+}$; хлору та хлорпохідних; радіоактивних летких продуктів поділу - парів йоду та йодистого метилу) [9].

Нами також визначено, що мікроструктура АВВНМ обмежується здебільшого мікрота мезопорами (до 200 нм), які складають основну масу поверхні АВВНМ. Від наявності пор різного розміру залежить вибірковий характер сорбції високо-, середньо- та низькомолекулярних сполук. Зокрема, мікропорам властивий підвищений адсорбційний потенціал щодо дрібних молекул, тому молекули газів та парів ефективніше сорбуються в мікропорах АВВНМ, сумірних з ними за розмірами [9]. Мезопори більш доступні забруднювачам ат- 


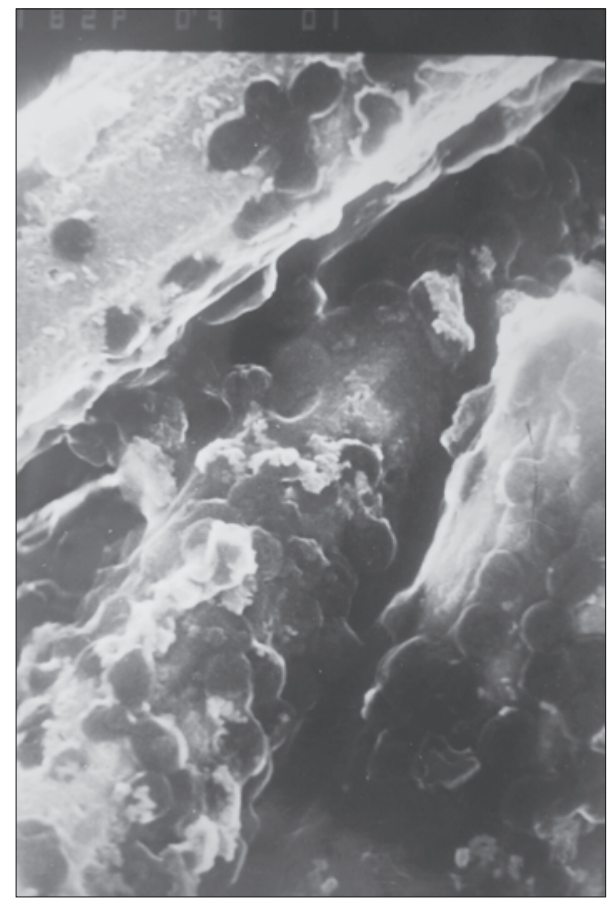

Puc. 2. Клітини золотавого стафілокока на поверхні мікроволокон АВВНМ $(\times 5000)$ мосфери $\mathrm{PM}_{2.5}$ та $\mathrm{PM}_{10}(2,5-10$ нм) і вірусу COVID-19 (розмір 100-120 нм), що надає перспективи у використанні АВВНМ для виготовлення захисної маски широкого спектра дії.

Позаяк біологічні забруднювачі атмосферного повітря (пилкові зерна, спори пліснявих грибів, органічний пил та токсини мікроорганізмів) мають здебільшого білкову природу, тому ефективність їхньої сорбції на АВВНМ ми оцінювали за ступенем поглинання альбумінів, гамма-глобулінів, ферментів [11]. Встановлено, що досліджуваний вуглецевий матеріал зв’язує білки міцніше за інші полімерні матеріали.

Щоб оцінити сорбційну активність АВВНМ відносно мікроорганізмів, визначали ефективність сорбції бактерій з їхніх водних суспензій та ріст колонієутворювальних одиниць на твердих живильних середовищах. Оцінка кінетики сорбції та сорбційної ємності матеріалів щодо санітарно-показових мікроорганізмів (Staphylococcus aureus, Escherichia coli та Pseudomonas aeroginosa) свідчить про істотні переваги АВВНМ порівняно з відомими вуглецевими сорбентами карболен, СКН та волокнистим сорбентом актилен [12].

Зокрема, на рис. 2 наведено мікрознімок осадження та утримання на АВВНМ одного 3 видів бактерій, що присутні у повітрі і здатні спричиняти ураження дихальних шляхів (ангіну, пневмонію) - Staphylococcus aureus. Як видно, клітини золотавого стафілокока, в стані інактивації та деструкції міцно прикріплені до бічних поверхонь вуглецевих мікроволокон, що, на думку авторів, вказує на незворотність реакції сорбції мікроорганізмів.

Процес сорбції мікроорганізмів (зокрема, бактерій), розміри яких більші за розміри мікро- та мезопор у АВВНМ (а кількість макропор у матеріалі незначна), відбувається, вірогідно, не за внутрішньо-дифузійним механізмом, а головним чином на геометричній поверхні АВВНМ. Розміри вірусів, зокрема коронавірусів (100-120 нм), значно менші за розміри бактерій, тому для їхньго уловлювання та дезактивації В. Баулін (Університет Ровіра і Вірхілій, Іспанія) радить застосовувати матеріали з наноструктурною поверхнею, використовуючи їхні нанокомпоненти (розмір 1-100 нм) як пастку для вірусів із зістав-

Кінетика стабільності колоній E. coli у воді при контакті з АВВНМ та АВВНM-Ag

\begin{tabular}{|c|c|c|c|}
\hline \multirow{2}{*}{ Зразок } & \multicolumn{2}{|c|}{ Кількість мікробів (КУО) в 1 мл води за різної експозиції, год } \\
\cline { 2 - 4 } & 0,5 & 1 & 2 \\
\hline Контроль & $200 \cdot 10^{3}$ & $200 \cdot 10^{3}$ & $200 \cdot 10^{3}$ \\
АВВНМ & $200 \cdot 10^{3}$ & $190 \cdot 10^{3}$ \\
АВВНМ-Ag & $80 \cdot 10^{3}$ & $60 \cdot 10^{3}$ & $150 \cdot 10^{3}$ \\
$20 \cdot 10^{3}$
\end{tabular}


ними розмірами. Інші дослідники [5] припускають, що сорбційна взаємодія відбувається між функціональними групами на поверхі вуглецевих матеріалів і амінокислотними групами гемаглютиніну вірусу грипа. Розроблений нами АВВНМ, як вказано вище, має в своєму складі різні наноформи та значну кількість функціональних груп на своїй поверхні, тобто зможе якісно утримувати як бактерії, так і віруси, осаджені з повітря.

Таким чином, сорбція та механічне утримування мікробів на поверхні АВВНМ перешкоджає їхньому потраплянню до дихальних шляхів людини і пригнічує ріст та розмноження, забезпечуючи у такий спосіб бактеріостатичну активність матеріалу. Але накопичення мікробів на фільтрувальному прошарку масок багаторазового застосування потребує більш інтенсивного знешкодження осаджених мікроорганізмів за допомогою як фізичних факторів (температура, висушування, променева енергія, ультразвук, осмотичний тиск та ін.), так і хімічних речовин (дезінфектанти та антисептики неспецифічної дії). Так, вчені з Ізраїльського технологічного інститут м. Хайфа під час розробки багаторазової маски використовували знезаражувальну дію термонагрівання електричним струмом фільтрувального прошарку із вуглецевих волокон. Автори роботи [13] також рекомендують застосовувати руйнівний вплив підвищеної температури та ультразвуку на життєдіяльність вірусу грипу А/Вікторія/361/11, А/Швейцарія/9715293/13 (H3N2).

3 метою хімічного знезараження маски просочують антисептичними лікарськими засобами, зокрема октенісептом (пат. 2127619 РФ. Лицевая маска или повязка. Опубл. 20.03.1999) та покривають благородними металами, зокрема сріблом (пат. 49742 (2006), 49744 (2010) і 50693 (2010) Україна).

Беручи до уваги вищезгадане, нами були проведені пошуки можливостей знезараження АВВНМ за рахунок використання фізичних та хімічних факторів. 3 цією метою вивчали електропровідність та теплофізичні характеристики матеріалу. Визначено, що питомий електроопір АВВНМ становить 0,8 мкОм · м при питомій поверхні $2800 \mathrm{~m}^{2} /$ г, що менше, ніж у матеріалі ТГН-2МК (1,3 мкОм · м при питомій поверхні 700 м²/г), який застосовується в хірургічних пов’язках “Карпема” (РФ). Низький електроопір, властивий АВВНМ, має забезпечити ефективне знезараження матеріалу при пропусканні електричного струму (зокрема, у багаторазових захисних масках для обличчя). Для створення вказаних виробів також важливо визначити теплофізичні характеристики матеріалу. Так, наші дослідження показали, що теплоємність АВВНМ при температурі 298,15 К більша (1674 Дж/(кг К К)), ніж у графіту та вуглецевої тканини УУТ-2 (відповідно 718 та 1368 Дж/(кг · К)) [14]. Таким чином, висока електропровідність АВВНМ, використаного як фільтрувальний матеріал, дає можливість дезактивувати мікроорганізми електричним струмом (по аналогії 3 розробкою ізраїльських вчених), а висока теплостійкість матеріалу гарантує збереження експлуатаційних показників при багаторазовому використанні.

Для покращення біоспецифічних властивостей АВВНМ нами проведена іммобілізація наночастинок та іонів срібла на ABBHM і отримано зразки ABBHM-Ag [15]. При цьому необхідно зазначити, що АВВНМ є ефективною матрицею для антимікробних агентів через наявність на поверхні значної кількості ненасичених зв’язків і характеризується змінюваною адгезивністю за рахунок текстильної структури.

На наступному етапі роботи нами досліджено кінетику стабільності мікробної популяції E. coli $\left(2 \cdot 10^{5}\right.$ КУО/л) у дехлорованій воді в присутності зразків АВВНМ та АВВНМ-Ag. 
Кількісний підрахунок зон росту колоній на чашках Петрі проводили через 24 год після висіву. Контролем слугували посіви проб води, що не контактували зі зразками АВВНМ та АВВНM-Ag.

Як видно з таблиці, зразок АВВНМ виявляє слабковиражені бактерицидні властивості щодо E. coli на відміну від модифікованого сріблом зразка. Таким чином, бактеріостатичні властивості АВВНМ можуть бути трансформовані в бактерицидні шляхом нанесення на поверхню речовин, які спричиняють загибель сорбованих мікробних клітин, що є цінним для розробки самовідновлювальної маски.

\section{Висновки.}

1. АВВНМ притаманна висока здатність до поглинання основних забруднювачів довкілля хімічної, фізичної та біологічної природи, чим забезпечується ефективна фільтрація атмосферного повітря.

2. АВВНМ виявляє бактеріостатичні властивості, які можуть бути трансформовані в бактерицидні шляхом нанесення на його поверхню наночастинок срібла, що можна використати для знезараження фільтрувального прошарку маски.

3. Електропровідність та теплостійкість АВВНМ уможливлюють знезараження фізичними методами.

4. АВВНМ відповідає більшості вимог до матеріалів медичного призначення і може бути рекомендований для виготовлення масок для захисту органів дихання від токсичних речовин, вірусів тощо.

\section{ЦИТОВАНА ЛІТЕРАТУРА}

1. Jackson J., Hodges K. How air pollution may influence the course of pandemics. Sci. Adv. 2020. 6, № 45. eabf1897. https://doi.org/10.1126/sciadv.abf1897

2. Турос О.І., Маремуха Т.П., Петросян А.А., Брезицька Н.В. Дослідження забруднення атмосферного повітря зваженими частинками пилу $\left(\mathrm{PM}_{10}\right.$ та $\left.\mathrm{PM}_{2,5}\right)$ у м. Києві. Довкілля та здоров'я. 2018. № 4. C. 36-39. https://doi.org/10.32402/dovkil2018.04.036

3. Кирш А.А., Будыка А.К., Кирш В.А. Фильтрация аэрозолей волокнистыми материалами ФП. Рос. хим.ж. (Ж. Рос. хим. об-ва им. Д.И. Менделеева). 2008. 52, № 5. С. 97-102.

4. Єсилевський C.O. Раби і маски: трагікомедія помилок. Medium. URL: https://yesylevskyy.medium.com/ рабы-и-маски-трагикомедия-ошибок-f541d4683f7c (Дата звернення: 23.11.2020).

5. Иванова В.Т., Иванова М.В., Бурцева Е.И., Гарина Е.О., Трушакова С.В., Шевченко Е.С., Маныкин А.А., Исакова А.А., Корженевский А.П., Спицын Б.В. Взаимодействие вирусов гриппа А и В с сорбентами на основе наноалмазов. Вопросы вирусологии. 2012. 57, № 2. С. 9-13.

6. Рачковская Л.Н., Летягин А.Ю., Бурмистров В.А., Королев М.А., Гельфонд Н.Е., Бородин Ю.И., Коненков В.И. Модифицированные сорбенты для практического здравоохранения. Сиб. науч. мед. журн. 2015. 35, № 2. С. 47-54.

7. Лысенко А.А. Основы ресурсосберегающих технологий получения активированных углеродных волокон, их свойства и применение: дис. ... д-ра тех. наук / Санкт-Петербургский государственный университет технологии и дизайна. Санкт-Петербург, 2007.

8. Кононко І.В., Сергєєв В.П., Щербицька О.В., Кліпов В.Д., Кононко Н.В. Вуглецеві наноструктурні матеріали: токсичність та біосумісність. “Вісник” УМТ. 2015. № 1. С. 58-67.

9. Кононко І.В., Щербицька О.В., Кліпов В.Д., Сергєєв В.П., Уварова І.В. Вуглецевий наноструктурний волокнистий матеріал та екологія. Застосування для захисту довкілля. Довкілля та здоров'я. 2014. № 4. С. 24-29.

10. Григорьева Т.К., Карнацевич Л.В., Колобродов В.Г., Левикова Л.В., Сергеев В.П., Литвинов В.Ф., Кондратюк П.П. Адсорбционные характеристики активированных углеродных волокнистых мате- 
Вуглецевий наноструктурний матеріал для багаторазових захисних масок

риалов типа АУВМ “Днепр”. Вопросы атомной науки и техники. Сер. Ядерно-физические исследования (Теория и эксперимент). 1991. Вып. 1. № 19. С. 9-14.

11. Портной О.А., Николаев В.Г., Фридман Л.И., Белкин А.Л., Пострелко Т.Н., Пендрак К.А., Ерецкая Е.В., Пожиткова М.С., Снежкова Е.А., Иванова А.Б. Исследование сорбции биологических веществ активированными углеродными волокнами. Химико-фармащ. журн. 1984. 18, № 3. С. 360-364.

12. Сергеев В.П., Рожавин М.А., Литвинов В.Ф., Баглей Н.Н. Микробиологические исследования сорбции различных видов бактерий аппликационным АУВМ “Днепр” МН. Современные подходы к разработке эффективных перевязочных средств и шовных материалов: Тез. докл. I Всесоюз. конф. Москва, 1989. С. 25-26.

13. Иванова В.Т., Гарина Е.О., Сапурина И.Ю., Стейскал Я., Грибкова О.Л., Кириллова Е.С., Иванов В.Ф., Бурцева Е.И. Влияния различных факторов на сорбционные взаимодействия электропроводящего полимера с вирусами гриппа. Сорбционные и хроматографические процессы. 2017. 17, № 4.С. 592-600. https://doi.org/10.17308/sorpchrom.2017.17/417

14. Сергеев В.П., Литвинов В.Ф., Кириченко В.И., Бурушкина Т.Н. Теплофизические и адсорбционные свойства углеродных волокнистых материалов. Вопросы атомной науки и техники. 1977. Вып. 2. С. $62-64$.

15. Кононко І.В., Кліпов В.Д., Бошицька Н.В., Проценко Л.С., Кононко Н.В. Особливості іммобілізації наносрібла на активовану вуглецеву волокнисту наноструктурну матрицю для розробки антибактеріальних матеріалів медичного призначення. Допов. Наи. акад. наук Укр. 2019. № 11. С. 49-56.

https://doi.org/10.15407/dopovidi2019.11.049

Надійшло до редакції 13.07.2021

\section{REFERENCES}

1. Jackson, J. \& Hodges, K. (2020). How air pollution may influence the course of pandemics. Sci. Adv., 6, No. 45, eabf1897. https://doi.org/10.1126/sciadv.abf1897

2. Turos, O. I., Maremukha, T. P., Petrosian, A. A. \& Brezitska, N. V. (2018). Study of atmospheric air pollution with particulate matters $\left(\mathrm{PM}_{10}\right.$ and $\left.\mathrm{PM}_{2.5}\right)$ in Kyiv. Environment and Health, No. 4, pp. 36-39 (in Ukrainian). https://doi.org/10.32402/dovkil2018.04.036

3. Kirsh, A. A, Budyka, A. K. \& Kirsh, V. A. (2008). Filtration of aerosols by fibrous materials FP. Ros. khim. zh. (Zh. Ros. khim. ob-va im. D.I. Mendeleyeva), 52, No. 5, pp. 97-102 (in Russian).

4. Yesilevsky, S. O. (2020). Slaves and masks: a tragicomedy of mistakes. Medium (in Ukrainian). Retrieved from https://yesylevskyy.medium.com/рабы-и-маски-трагикомедия-ошибок-f541d4683f7c

5. Ivanova, V. T., Ivanova, M. V., Burtseva, E. I., Garina, E. O., Trushakova, S. V., Shevchenko, E. S., Manykin, A. A., Isakova, A. A. , Korzhenevsky, A. P. \& Spitsyn, B. V. (2012). Interaction of influenza A and B viruses with nanodiamond-based sorbents. Vopr. Virusol., 57, No. 2, pp. 9-13 (in Russian).

6. Rachkovskaya, L. N., Letyagin, A. Yu., Burmistrov, V. A., Korolev, M. A., Gelfond, N. E., Borodin, Yu. I. \& Konenkov, V. I. (2015). Modified sorbents for practical public health. Siberian Scientific Med. Journal. 35, No. 2, pp. 47-54 (in Russian).

7. Lysenko, A. A. (2007). Fundamentals of resource-saving technologies for the production of activated carbon fibers, their properties and applications. (Extended abstract of Doctor Thesis). St. Petersburg University of Technology and Design, St. Petersburg (in Russian).

8. Kononko, I. V., Sergeev, V. P., Shcherbytska, O. V., Klipov, V. D. \& Kononko, N. V. (2015). Carbon nanostructured materials: toxicity and biocompatibility. Visnyk UMT, No. 1, pp. 58-67 (in Ukrainian).

9. Kononko, I. V., Shcherbytska, O. V., Klipov, V. D., Sergeev, V. P. \& Uvarova, I. V. (2014). Nanostructured fibrous carbon material and ecology. Using the material for environment protection. Environment and Health, No. 4, pp. 24-29 (in Ukrainian).

10. Grigorieva, T. K., Karnatsevich, L. V., Kolobrodov, V. G., Levikova, L. V., Sergeev, V. P., Litvinov, V. F. \& Kondratyuk, P. P. (1991). Adsorption characteristics of activated carbon fibrous materials such as AUVM "Dnepr". Voprosy atomnoy nauki i tekhniki. Ser. Yaderno-fizicheskiye issledovaniya (Theoriya i eksperiment), Iss. 1, pp. 9-14 (in Russian).

11. Portnoy, O. A., Nikolaev, V. G., Friedman, L. I., Belkin, A. L., Postrelko, T. N., Pendrak, K. A., Yeretskaya, E. W., Pozhytkova, M. S., Snezhgkova, E. A. \& Ivanova, A. B. (1984). Investigation of biological substances sorption by activated carbon fibers. Khimiko-farmats. zhurn., 18, No. 3, pp. 360-364 (in Russian). 
12. Sergeev, V. P., Rozhavin, M. A., Litvinov, V. F. \& Bagley, H. H. (1989). Microbiological researches of various types of bacteria sorption by application A UVM "Dnepr" MN. Proceedings of the I All-Union Conference Modern approaches to the development of effective dressings and sutures (pp. 25-26), Moscow (in Russian).

13. Ivanova, V. T., Garina, E. O., Sapurina, I. Yu., Stejskal, J., Gribkova, O. L., Kirillova, E. S., Ivanov, V. F. \& Burtseva, E. I. (2017). Influences of various factors on the sorption interactions of conducting polymer with respect to influenza viruses. Sorbtsionnyye i khromatograficheskiye protsessy, 17, No. 4, pp. 592-600 (in Russian). https://doi.org/10.17308/sorpchrom.2017.17/417

14. Sergeev, V. P., Litvinov, V. F., Kirichenko, V. I. \& Burushkina, T. N.(1977). Thermophysical and adsorption properties of carbon fibrous materials. Voprosy atomnoy nauki i tekhniki, Iss. 2, pp. 62-64 (in Russian).

15. Kononko, I. V., Klipov, V. D., Boshytska, N. V., Protsenko, L. S. \& Kononko, N. V. (2019). Features of the immobilization of nanosilver on an activated carbon fiber nanostructural matrix for the development of antibacterial materials for medical use. Dopov. Nac. akad. nauk Ukr., No. 11, pp. 49-56 (in Ukrainian).

https://doi.org/10.15407/dopovidi2019.11.049

Received 13.07.2021

I.V. Kononko, https://orcid.org/0000-0003-1976-7116

N.V. Boshytska, https://orcid.org/0000-0003-2241-1161

V.P. Sergeev, https://orcid.org/0000-0001-9417-2548

V.D. Klipov, https://orcid.org/0000-0002-5634-1512

N.V. Kononko, https://orcid.org/0000-0002-5634-1512

Frantsevich Institute for Problems of Materials Science of the NAS of Ukraine, Kyiv

E-mail: nata25lia@gmail.com

\section{CARBON NANOSTRUCTURED MATERIAL} FOR MULTIPLE PROTECTIVE MASKS

The complex of properties of the activated carbon fiber nanostructured material (AVVNM) developed by the authors as a filter layer of multiple protective face masks has been investigate. It is shown that AVVNM has a high ability to absorb the main environmental pollutants (phenol; metals $\mathrm{Pb}^{2+}, \mathrm{Sr}^{2+}, \mathrm{Cu}^{2+}, \mathrm{Ni}^{1+}, \mathrm{Co}^{2+}, \mathrm{Al}^{3+}$, $\mathrm{Cs}^{2+}$; chlorine derivatives; radioactive volatile decay products, etc.) and substances of the protein nature. It has been established that AVVNM exhibits the bacteriostatic properties which can be transformed into bactericidal ones by applying the biologically active substances on the material surface. It is proved that AVVNM meets the requirements for medical materials and can be recommended for the manufacture of protective masks.

Keywords: masks for respiratory protection, activated carbon fiber nanostructured material, physico-chemical properties. 